\title{
Demographic change as a driver for tourism automation
}

\author{
Craig Webster and Stanislav Ivanov
}

\begin{abstract}
Purpose - The purpose of this paper is to discuss how demographic changes in developed countries will continue to drive the tourism and hospitality industries to adopt automation in business operations.

Design/methodology/approach - The approach is an analysis of the trends in human reproduction in the developed countries and a discussion of their implications for the travel, tourism and hospitality industries.

Findings - There are three major solutions to the demographic problem faced in developed countries and the replacement of human labour with automation is the most practical, immediate and has the fewest risks and negative externalities.

Practical implications - Industry has to adapt to the new demographic reality and embrace automation of services, educate their customers and have policies to deal with the resistance expected by labour.

Social implications - Society can expect that many of the tasks they commonly expect humans to be involved in will be done by machines and artificial intelligence in the near future, if demographic trends continue and massive immigration into developed countries is not a continuing phenomenon.
\end{abstract}

Originality/value - This links the relationship between demographic trends to the use of automation in the travel, tourism and hospitality industries.

Keywords Robots, Demography, Artificial intelligence, Service automation, Population decline

Paper type Research paper

\section{Introduction}

Demographic change is one of the constants in human society. Historically, some groups have squeezed out other groups or massive incursions of population have occurred into new regions of the earth. For example, the migrations of people from the east into central Europe about 1,500 years ago (Goffart, 2006) changed the human geography of Europe a great deal, the slave trade across the Atlantic until a century and a half ago changed the demographics of the USA (Inikori and Engerman, 1992) and the current migration of people into the Western world from less developed countries is changing the demographics and landscape of developed countries (Coleman, 2008). Here, we look into the current demographic challenge of the developed world and discuss the strengths and weaknesses of the three policy responses, highlighting how the third solution, the embracing of further automation of service industries, seems to be the best of the three choices. First, we look into the severity of the current demographic trends in developed countries, then we highlight the three solutions to the problem, concluding with how service automation will likely be the best solution but leave behind some serious externalities that policymakers will have to contend with. Then, we link the automation solution to pragmatic issues that managers in travel, tourism and hospitality will have to take into account when incorporating automation into their enterprises.

There has been a revolution in human reproduction in recent decades composed of several components which has implications for travel, tourism and hospitality (Webster, 2019). The
Craig Webster is based at the Department of Family and Consumer Sciences, Ball State University, Muncie, Indiana, USA. Stanislav Ivanov is based at the Department of Tourism, Varna University of Management, Varna, Bulgaria.

Received 27 October 2019 Revised 1 February 2020 Accepted 1 February 2020

(C) Craig Webster and Stanislav Ivanov. Published in Journal of Tourism Futures. Published by Emerald Publishing Limited. This article is published under the Creative Commons Attribution (CC BY 4.0) license. Anyone may reproduce, distribute, translate and create derivative works of this article (for both commercial and non-commercial purposes), subject to full attribution to the original publication and authors. The full terms of this license may be seen at http://creativecommons. org/licences/by/4.0/legalcode 
major component is the development of technologies that enable females to control the reproductive process as never before. The birth control pill, approved by the FDA in 1960 (Christin-Maitre, 2013), was the first modern technology that enabled women to separate vaginal intercourse from reproduction in an effective manner (Bullough and Bonnie, 1990). It is qualitatively different from the condom, as the female has almost complete control over the intake and use of the pill, unlike the condom which requires the cooperation of the male partner. There were other technological changes/ innovations that have increased the ability of humans to separate vaginal intercourse from procreation, including the IUD, the diaphragm and several other forms and delivery systems (such as contraceptive injections and patches). This was a technological revolution that enabled increased control of women over their reproduction. At the same time, since the 1960s, there has been a liberalization of rules regarding abortion in the West, innovations that allow for chemically induced abortions in the home (the "morning after pill") and decriminalization of same sex sexual encounters. All-in-all, the social, legal and technological changes have led to a world in which there is greater control with regards to reproduction and reproduction is more of a conscious choice than ever before (Jackson, 2001; Ruhl, 2002).

With people using contraception, feeling free to have sexual relations with people of the same sex and aborting fetuses (either in medical facilities or chemically at home), there has been a massive change in the demographics of developed countries. While the changes have been most drastic in developed countries, it seems that the technologies and social and legal changes have also impacted upon less developed countries, as well. The most noteworthy outcome of these changes has been the demographics of the developed countries, as the reproduction rates of the developed countries is below replacement levels (Castles, 2003; Faus-Pujol, 2005; OECD, 2016), when replacement levels are considered 2.1 children per woman. Figure 1 illustrates that the developed countries have birth rates that are far below population replacement levels. In addition, Figure 2 illustrates further that the current levels of fertility is a part of a general trend, even among some of the less developed and socially conservative countries, meaning that the new technologies and social/legal changes have led to a new reality for many population, leading to lower birth rates across the board (paradoxically, one of the only countries that seems to have increasing fertility rates in the past few decades is Israel, according to the OECD data).

\section{Figure 12017 fertility rates of selected countries}

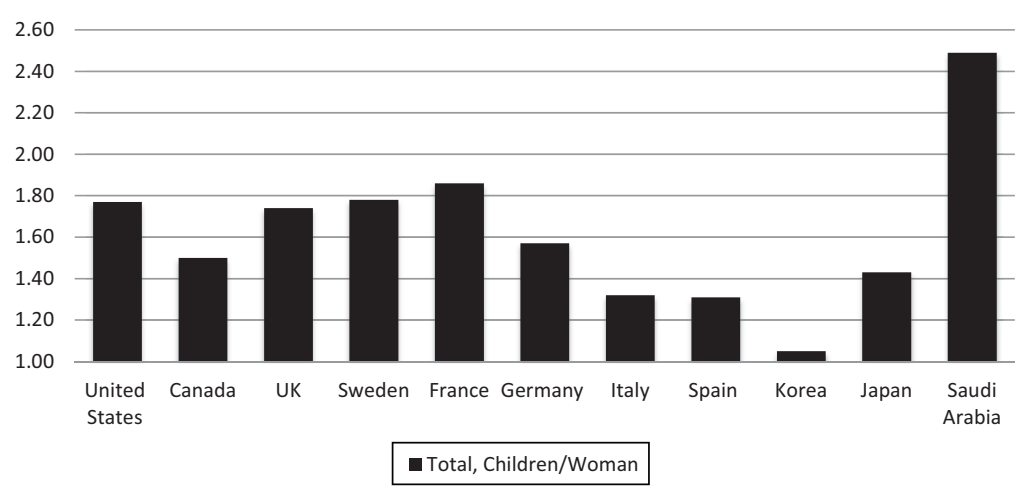

Source: OECD (2019) 


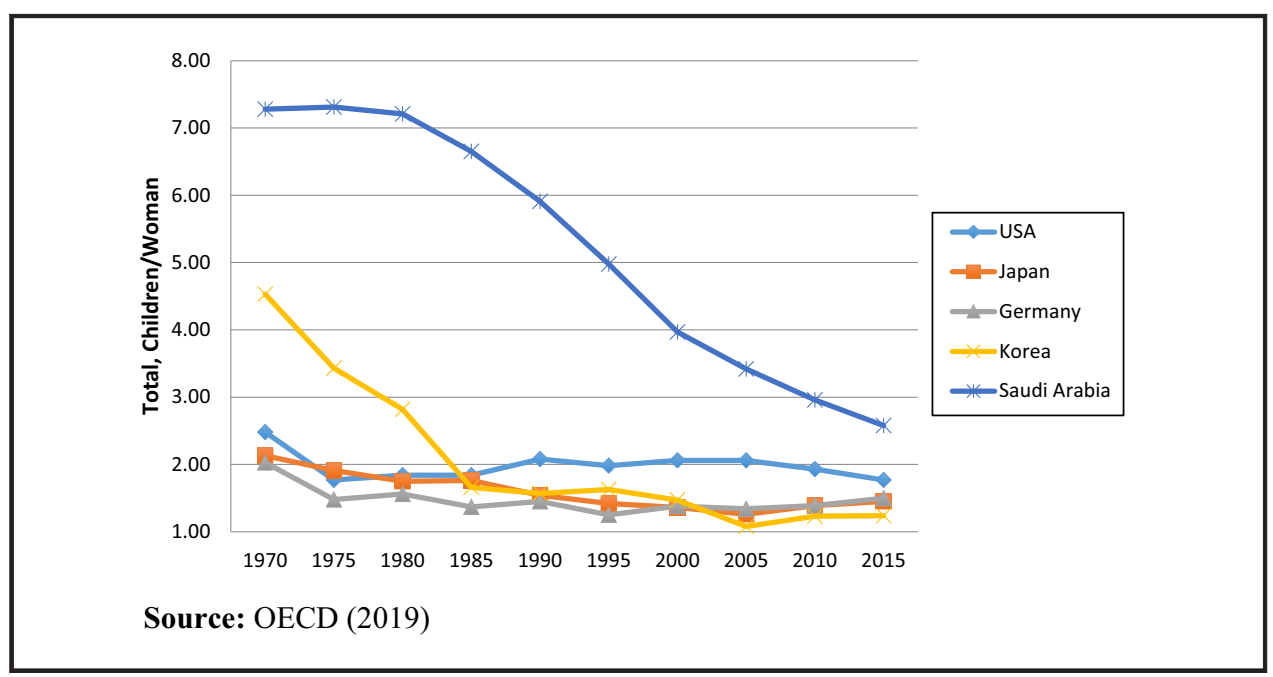

There are some curious nuances to the demographic changes in recent decades because birth rates are uneven among ethnic/religious groups and because of the ethnic/religious/ racial groups emigrating since Second World War. For example, by 2049, the majority of the US population will no longer be "white" (Frey, 2014). The immigration of Muslim population into countries that are Western is noted to be a difficult integration process (Koopmans, 2015; Mohiuddin, 2017). Even though there is migration into countries in which the population are well below replacement levels, the migration is likely not enough to ameliorate the labour shortages in many occupations in the near future (Cappelli, 2005). With this demographic transition, population declines not only threaten to lead to severe labour shortages but also lead to the periodic ratcheting up of retirement ages in developed countries, as the demographic pyramid of developed countries translates into problems funding a welfare state for older citizens.

\section{The solutions}

There are three likely solutions to the demographic problem faced in developed countries, as there is a lack of young labour to do the work needed in the economy (Ivanov and Webster, 2019d) and each of these solutions has a different probability of success, speed of implementation and externality of the solution, as Table I shows. The first is to encourage

\section{Table I Solutions to the demographic crisis}

\begin{tabular}{|c|c|c|c|c|}
\hline Solution & $\begin{array}{l}\text { Probability } \\
\text { of success }\end{array}$ & $\begin{array}{l}\text { Speed of } \\
\text { introduction } \\
\text { of solution }\end{array}$ & $\begin{array}{l}\text { Probability of } \\
\text { negative social } \\
\text { externalities }\end{array}$ & Problems with the solution \\
\hline $\begin{array}{l}\text { Increase reproduction } \\
\text { by women in developed } \\
\text { countries }\end{array}$ & Low & $\begin{array}{l}\text { Slow (about } \\
\text { two decades) }\end{array}$ & Low & $\begin{array}{l}\text { Social resistance, lack of } \\
\text { resources to fund incentives }\end{array}$ \\
\hline $\begin{array}{l}\text { Immigration to } \\
\text { developed countries } \\
\text { from less developed } \\
\text { countries }\end{array}$ & High & $\begin{array}{l}\text { Rapid (a few } \\
\text { months) }\end{array}$ & High & $\begin{array}{l}\text { Social resistance, nativist } \\
\text { reactions, culture clash }\end{array}$ \\
\hline $\begin{array}{l}\text { Replacement of human } \\
\text { tasks with robots/ } \\
\text { artificial intelligence }\end{array}$ & High & $\begin{array}{l}\text { Rapid (a few } \\
\text { weeks- } \\
\text { months) }\end{array}$ & Low & $\begin{array}{l}\text { Labour/trade union } \\
\text { resistance, Luddites, } \\
\text { resistance from customers }\end{array}$ \\
\hline
\end{tabular}


people in developed countries to have more children. The simplicity of this solution is also what makes it attractive, all that needs to be done is the discovery of an incentive structure to encourage people to have more children. The weakness of this, however, is that the solution goes against a general trend in societies enabled by social and technological changes. It seems that inducements generally do not reverse this demographic trend, as the "baby bonus" that several countries have instituted have not caused a major change in birth rates in developed countries. For example, there is no evidence that over ten years that the baby bonus of Australia has a noteworthy impact on births (Deutscher and Breunig, 2018; Laetitia and Takongmo, 2018). Even if by some way developed countries could encourage people to have more children, the impact on the labour force would take some time to be felt, as babies born today would not be expected to enter the workforce for nearly two decades.

The second likely solution is to allow for immigration from countries with a surplus of people/ labour. This is a simple solution that would have immediate effects upon industry, as labour could be imported from where it is in abundance to where it is in short supply. Here, the externalities are an issue, as the imported population will bring cultural habits that may be unwanted in the host country. For example, the rise in reported rapes in western Europe may suggest that it is a function of massive immigration from outside of Europe in recent years (BBC, 2019), although this has been refuted by some (The Local, 2019). While some of the cultural baggage, including religion, may or may not be entirely negative for the host population, massive immigration is a politically divisive issue. So, while it is a quick fix to labour shortages because of the lack of reproduction in developed countries, it may come with cultural and political externalities that are hard for many in the host population to accept.

The third likely solution is to replace tasks with robots and artificial intelligence so that capital will replace human labour where possible. Thus, the replacement of human tasks for robots and artificial intelligence will enable human labourers to do more work with less human labour. In a world with diminishing numbers of people, this is a solution that will kick in immediately, as robots and software can be manufactured faster than humans can reproduce and get a human up to speed to work in a workplace. In addition, there is little culture clash involved in the use of machines, although generations of customers will have to be introduced to the new technologies and learn how to use them. The downside, though, is the issue linked with labour, as there is a threat that human labour may resent the incursion of robots and artificial intelligence into the workplace, fearing a displacement of members of the workforce. Much of the resistance by human labour rests on the extent of the ability of technologies to automate tasks. While to some extent, automation may remove some of the dull, dirty or dangerous tasks from the humans, if the extent of automation is very great, then automation may replace many humans in the workplace. The degree of automation will largely be dependent upon the capabilities of new technologies and the political regulation of such technologies.

All-in-all, the three solutions (summarized in Table I) illustrate that the replacement of human tasks with machines is the best of the three choices on many dimensions. For one thing, the probability of success of the replacement of humans with robots will be high, as there are some tasks that may easily be automated (Ivanov and Webster, 2019a, 2019b, 2019e). The speed of the introduction of the solution may be much more immediate with service automation, as machines can take over many tasks that many humans now do almost immediately and the major problems faced in the implementation of the automated solution will be resistance from workers and some customers. Already, there is indication that there are different market segments that are more resistant to using robots and artificial intelligence than others (see, for example, Ivanov and Webster, 2019a, 2019b; Ivanov et al., 2018a; Ivanov et al., 2018b). 


\section{Implications for tourism}

The demographic situation of the developed countries requires the tourism and hospitality industries to rethink how they use automation and labour. As the workforce in developed countries ages and retires, the scarcity of human labour will force industry to look for something or someone to do the many tasks that need to be done. Here, we have shown that there are three policy choices to solve the problem of the increasing scarcity of labour in developed countries; all have lag times, strengths and externalities associated with them. Of the three major policy choices, the replacement of human labour with systems of automation will solve the problem of the shortage of labour fastest and has the least negative externalities. However, this solution also requires management to rethink who does tasks and how tasks are to be done in the tourism and hospitality industries. It will also require the rethinking of taxation systems to fund the welfare state (Webster and Ivanov, 2020).

Already, many of the tasks in travel, tourism and hospitality that had previously been done by humans have been automated and this will continue to disrupt the industries (Ivanov, 2019; Ivanov and Webster, 2019c). For example, in just a few years, many travel agents who were responsible for finding flights for customers have been bypassed, as customers routinely purchase their own tickets without using the services of a travel agent. In a similar way, many check-ins in airports are automated. The automation of travel, tourism and hospitality in developed countries is inevitable, as the technologies are available (and improving) and the demographics favour the implementation of the new technologies. At any rate, a great deal of robots and other service automation technologies have already been implemented in the workplace in travel, tourism and hospitality (Ivanov et al., 2017).

There may be some impact of the automation of some services in the industry, as some customers may not react in a very positive way to the automation of some tasks. One danger is that automation may negatively impact upon the perception of the quality of service offered to customers, as there is considerable evidence that there are some who are not entirely receptive to further automation in the hospitality industry (Ivanov et al., 2018a; Ivanov et al., 2018b). However, as technologies progress, the customers' expectations will likely also evolve to expect automation and if the cost advantage of automation is passed along to the customer, then customers will likely embrace and accept such automation. Part of the increased use of automation will have to involve the industry showing how customers can use the technologies in an effective way and communicating to the customers that the technologies lead to a better quality of service or better prices. At any rate, the development of automation technologies and their implementation in the workplace will have a major impact on the workplace, taxation and the role of the human in the economy (Webster and Ivanov, 2020).

In closing, there are many trends and changes that should be watched with regards to travel, tourism and hospitality in the future. While there are short-term political concerns that have been thought to have an impact on travel, tourism and hospitality such as the election of Donald Trump in the USA (Le, 2017; Webster, 2017) and longer-term political concerns such as the creation of large political and economic blocs (Webster and Ivanov, 2015), there seems to be a much more biologically based change that has a major impact upon labour markets. The long-term demographic transition and its uneven application globally presents humanity with serious challenges since the contraceptive pill received FDA approval in 1960. This biologically based driver into the future has implications for political decisions and technological responses to the problems brought on by the dearth of human births. The further automation of service industries in developed countries would also have an externality that is a major concern, as it risks exacerbating the youth bulge in developing countries (Inayatullah, 2017). So the increased automation of service industries in the developed countries solves some problems quickly but also leads to some externalities that will inflame serious social and political problems in the less developed world. 


\section{References}

BBC (2019), "Sweden rape: most convicted attackers foreign-born, says TV", available at: www.bbc. com/news/world-europe-45269764 (accessed 20 October 2019).

Bullough, V.L. and Bonnie, B. (1990), Contraception: A Guide to Birth Control Methods, Prometheus Books, Buffalo, New York, NY.

Cappelli, P. (2005), "Will there really be a labor shortage?", Human Resource Management, Vol. 44 No. 2, pp. 143-149.

Castles, F. (2003), "The world turned upside down: below replacement fertility, changing preferences and family-friendly public policy in 21 OECD countries", Journal of European Social Policy, Vol. 13 No. 3 , pp. 209-227.

Christin-Maitre, S. (2013), "History of oral contraceptive drugs and their use worldwide", Best Practice \& Research Clinical Endocrinology \& Metabolism, Vol. 27 No. 1, pp. 3-12.

Coleman, D. (2008), "The demographic effects of international migration in Europe", Oxford Review of Economic Policy, Vol. 24 No. 3, pp. 452-476.

Deutscher, N. and Breunig, R. (2018), "Baby bonuses: natural experiments in cash transfers, birth timing and child outcomes”, Economic Record, Vol. 94 No. 304, pp. 1-24.

Faus-Pujol, M.C. (2005), "Changes in the fertility rate and age structure of the population of Europe", in Hall, R. and White, P. (Eds), Europes Population, Routledge, London, pp. 21-33.

Frey, W.H. (2014), Diversity Explosion: How New Racial Demographics Are Remaking America, Brookings Institution Press.

Goffart, W.A. (2006), Barbarian Tides: The Migration Age and the Later Roman Empire, University of PA Press.

Inayatullah, S. (2017), "Youth bulge: demographic dividend, time bomb, and other futures", Journal of Futures Studies, Vol. 21 No. 2, pp. 21-34.

Inikori, J.E. and Engerman, S.L. (Eds) (1992), The Atlantic Slave Trade: effects on Economies, Societies and Peoples in Africa, the Americas, and Europe, Duke University Press.

Ivanov, S. (2019), "Ultimate transformation: how will automation technologies disrupt the travel, tourism and hospitality industries?", Zeitschrift Für Tourismuswissenschaft, Vol. 11 No. 1, pp. 25-43.

Ivanov, S. and Webster, C. (2019a), "What should robots do? A comparative analysis of industry professionals, educators and tourists", in Pesonen, J. and Neidhardt, J. (Eds), Information and Communication Technologies in Tourism 2019, Proceedings of the International Conference in Nicosia, Cyprus, 30.01-01.02.2019, Springer, Cham, pp. 249-262.

Ivanov, S. and Webster, C. (2019b), "Perceived appropriateness and intention to use service robots in tourism", in Pesonen, J. and Neidhardt, J. (Eds), Information and Communication Technologies in Tourism 2019, Proceedings of the International Conference in Nicosia, Cyprus, 30.01-01.02.2019, Springer, Cham, pp. 237-248.

Ivanov, S. and Webster, C. (Eds) (2019c), "Robots, Artificial Intelligence and Service Automation in Travel, Tourism and Hospitality," ISBN: 978-1-78756-688-0, Emerald Publishing, London.

Ivanov, S. and Webster, C. (2019d), "Conceptual framework of the use of robots, artificial intelligence and service automation in travel, tourism, and hospitality companies", in Ivanov, S. and Webster, C. (Eds), Robots, Artificial Intelligence and Service Automation in Travel, Tourism and Hospitality, ISBN: 978-178756-688-0, Emerald Publishing, London, pp. 7-37.

Ivanov, S. and Webster, C. (2019e), "Economic fundamentals of the use of robots, artificial intelligence and service automation in travel, tourism and hospitality", in Ivanov, S. and Webster, C. (Eds), Robots, Artificial Intelligence and Service Automation in Travel, Tourism and Hospitality, ISBN: 978-1-78756-688-0, Emerald Publishing, London, pp. 39-55.

Ivanov, S., Webster, C. and Berezina, K. (2017), "Adoption of robots and service automation by tourism and hospitality companies", Revista Turismo \& Desenvolvimento, Vols 27/28, pp. 1501-1517.

Ivanov, S., Webster, C. and Garenko, A. (2018a), "Young Russian adults' attitudes towards the potential use of robots in hotels", Technology in Society, Vol. 55, pp. 24-32. 
Ivanov, S., Webster, C. and Seyyedi, P. (2018b), "Consumers' attitudes towards the introduction of robots in accommodation establishments", Tourism, Vol. 66 No. 3, pp. 302-317.

Jackson, E. (2001), Regulating Reproduction: Law, Technology and Autonomy, Hart Publishing, Oxford and Portland, OR.

Koopmans, R. (2015), "Religious fundamentalism and hostility against out-groups: a comparison of Muslims and Christians in Western Europe", Journal of Ethnic and Migration Studies, Vol. 41 No. 1, pp. 33-57.

Laetitia, L. and Takongmo, C.M. (2018), "The impact of universal child benefits on family health and behaviours", Research in Economics, Vol. 72 No. 4, pp. 415-427.

Le, A. (2017), "Trump's presidency: the future of American tourism industry", Journal of Tourism Futures, Vol. 3 No. 1, pp. 8-12.

Mohiuddin, A. (2017), "Muslims in Europe: citizenship, multiculturalism and integration", Journal of Muslim Minority Affairs, Vol. 37 No. 4, pp. 393-412.

OECD (2016), Society at a Glance 2016: OECD Social Indicators, OECD Publishing, Paris, available at: https://doi.org/10.1787/9789264261488-en

Ruhl, L. (2002), "Dilemmas of the will: uncertainty, reproduction, and the rhetoric of control", Signs: Journal of Women in Culture and Society, Vol. 27 No. 3, pp. 641-663.

The Local (2019), "New crime study: rise in Sweden's rape stats can't be tied to refugee influx", available at: www.thelocal.se/20190529/increase-in-swedens-rape-statistics-cant-be-tied-to-refugee-influx-studysuggests (accessed 27 October 2019).

Webster, C. (2017), "Political turbulence and business as usual: tourism's future", Journal of Tourism Futures, Vol. 3 No. 1, pp. 4-7.

Webster, C. (2019), "Halfway there: the transition from 1968 to 2068 in tourism and hospitality", Zeitschrift Für Tourismuswissenschaft, Vol. 11 No. 1, pp. 5-23.

Webster, C. and Ivanov, S. (2015), "Geopolitical drivers of future tourist flows", Journal of Tourism Futures, Vol. 1 No. 1, pp. 58-68.

Webster, C. and Ivanov, S. (2020), "Robotics, artificial intelligence, and the evolving nature of work", in George, B. and Paul, J. (Eds), Digital Transformation in Business and Society: Theory and Cases, ISBN 978-3-030-08277-2, Palgrave Macmillan, Cham, Switzerland, pp. 127-143.

\section{Further reading}

OECD (2019), "Fertility rates", available at: https://data.oecd.org/pop/fertility-rates.htm (accessed 20 October 2019).

\section{About the authors}

Craig Webster is an Associate Professor in the Department of Management at Ball State University, USA. He has taught at Binghamton University, Ithaca College, the College of Tourism and Hotel Management and the University of Nicosia. His research interests include the political economy of tourism, public opinion analysis and human rights. Dr Webster is the Editor-in-Chief of Tourism Today, has published in many peer-reviewed journals internationally and is co-edited of the book Future Tourism: Political, Social, and Economic Challenges, an edited book published by Routledge. He currently teaches courses in Hospitality Management at Ball State University's Miller College of Business.

Stanislav Ivanov is currently a Professor and a Vice Rector (Research) at Varna University of Management, Bulgaria (www.vum.bg). Prof Ivanov is the Founder and Editor-in-chief of the European Journal of Tourism Research (http://ejtr.vumk.eu) and serves in the Editorial boards of over 30 other journals. His research interests include robonomics, robots in tourism/hospitality, revenue management, destination marketing, tourism and economic growth, political issues in tourism, etc. His publications have appeared in different academic journals - Annals of Tourism Research, Tourism Management, Tourism 
Management Perspectives, International Journal of Revenue Management, Tourism Economics, Journal of Destination Marketing \& Management, Journal of Heritage Tourism, Tourism Today, Tourism, Tourism and Hospitality Research, Tourism Planning and Development, International Journal of Hospitality and Tourism Administration, Technology in Society, Journal of Economic Studies, Journal of Southern Europe and the Balkans, South-Eastern Europe Journal of Economics and other journals. Stanislav Ivanov is the corresponding author and can be contacted at: stanislav.ivanov@vumk.eu

For instructions on how to order reprints of this article, please visit our website: www.emeraldgrouppublishing.com/licensing/reprints.htm

Or contact us for further details: permissions@emeraldinsight.com 